\title{
DEIXIS IN THE CLEVER SERVANT STORY
}

\author{
Azizah Liawati $^{1}$, Siska Rizkiani ${ }^{2}$, Agil Jamaludin ${ }^{3}$ \\ ${ }^{1}$ IKIP Siliwangi \\ ${ }^{2}$ IKIP Siliwangi \\ ${ }^{3}$ IKIP Siliwangi \\ ${ }^{1}$ azizahliawati07@gmail.com, ${ }^{2}$ siskarizkiani@gmail.com, ${ }^{3}$ agiljamaludin95@gmail.com
}

\begin{abstract}
Pragmatics is a study of contextual meaning. Finding out the context and meaning of a conversation can be learned through deixis. This research analyzes types of deixis such as personal, time and place deixis. This research discusing about recount text entitled "The Clever Servant" as the instrument of this study. This research applied a descriptive qualitative method. The steps to analyze data are searching the story, reading the story, finding the data based on three kinds of deixis above. In this research, there was 27 deixis found in the text. The most common type of deixis is person deixis with 19 words. Whereas place deixis has 5 words and time deixis has 3 words. In this study, the researcher find out that personal deixis is the dominant type in the text.
\end{abstract}

Keywords: Deixis, Pragmatics, The Clever Servant

\section{INTRODUCTION}

In human life, language is a very important thing. Language is used as a means of communication between humans. According to (Ondondo, 2015), understanding communication and how it works is important to human beings. For this reason, learning languages is a things that must be done to preserve the language itself. In general, language also consists of two types, spoken language and written language.

Spoken language used for communicate directly in social life through a conversation. According to Brown (2004: 140) in Parmawati (2018) "speaking is a productive skill that can be directly and empirically observed, those observations are invariably colored by the accuracy and effectiveness of the test-takers listening skill, which necessarily compromises the reliability and validity of an oral production test". While the written language is communication indirectly or through text as a communication tool. In pragmatics it has three very problematical properties include deixis, utterances as speech acts and implicature. In this study, the researcher focuses on deixis. Language is a part of literature consisting of semantics, pragmatics, prepositions, speech acts, deixis, and others. According to (Huang, 2018), pragmatics is the systematic study of meaning by virtue of, or dependent or the use of language. (Saputri, 2015), states that deixis is to do with an indeterminacy that can be resolved when researcher look at the context, and particularly at three aspects of that context who the speaker is and where and when the sentence is uttered. (Jumanto , 2014) also stated that deixis is used to denote the element in a language which refer directly to the situation. From the explanation above it can be concluded that deixis is the study of how to analyze a word or phrase that is related to people, place and time.

In this study, researchers focused on person, place and time deixis in a recount text entitled "The Clever Servant". It is known that several types of text that researcher can be learnt in 
English, is like narrative, recount, descriptive, and others. But here the researcher takes recount text as the theme because in a recount text someone can tell a story or experience about his past. According to (Frans, 2010), recounting the text is telling the reader what happened. It retells a past event. It begins by telling the audiens who was involved, what happened, and where this event looks place. In the recount text, we can also analyze what deixis is contained in it, the analysis can also help us understand the contents of the story or text. The objectives of this research is to analyze and find out the kinds of deixis in the story of "The Clever Servant".

\section{METHOD}

In this study, the researchers used a descriptive qualitative method. According to Apsari (2017) states qualitative research is syntheticor holistic, heuristic, with little or no control and manipulation of the research content. The instrument took in this study was document analysis about recount text. The title is "The Clever Servant" by Kumala Velu. The researcher used this text because this text is interesting and easy to understand.

In this study procedure, the researcher followed these steps. The first, the researcher searches recount text with the title "The Clever Servant" from Seri Pendalaman Materi (SPM) book 2012. The second, the researcher reads the text. The third, the researcher analyz data. The researcher analysis the kinds of deixis. Finally, after analyze the data the researcher categorizes the result in the type of deixis. There are personal, time and place deixis.

\section{RESULTS AND DISCUSSION}

\section{Results}

After analyze the data. There are several types of deixis found in the text. They are personal, time, and place deixis.

Table.1 Personal Deixis in The Clever Servant Story

Table.1.1 First Person Deixis

\begin{tabular}{cc}
\hline Type First Person Deixis & Number of Words \\
\hline- & -
\end{tabular}

Based on the table above, first person deixis is not found in the text.

Table.1.2 Second Person Deixis

\begin{tabular}{cc}
\hline Type of Second Person Deixis & Number of Words \\
\hline You & 3 \\
\hline Total & 3 \\
\hline
\end{tabular}

Based on the table above, there is the words $Y o u$ as a type of second person deixis. The total words of these type are three.

Table.1.3 Third Person Deixis

\begin{tabular}{cc}
\hline Type of Third Person Deixis & Number of Words \\
\hline He & 7 \\
Him & 1 \\
\hline
\end{tabular}




\begin{tabular}{cc}
\hline His & 4 \\
They & 4 \\
\hline Total & 16 \\
\hline
\end{tabular}

Based on the table above, there are several words as third person deixis found in the text. He, him, his, and they. The total words of these type are sixteen.

Table.2 Time Deixis in The Clever Servant Story

\begin{tabular}{cc}
\hline Type of Time deixis & Number of Words \\
\hline This is an old story & 1 \\
Then & 1 \\
Every day & 1 \\
\hline Total & 3 \\
\hline
\end{tabular}

Based on the table above, there are several words as time deixis. This, then, and every day. The total words of time deixis are three.

Table.3 Place Deixis in The Clever Servant Story

\begin{tabular}{cc}
\hline Type of Place deixis & Number of Words \\
\hline Another town & 1 \\
This & 2 \\
There & 1 \\
That & 1 \\
\hline Total & 5 \\
\hline
\end{tabular}

Based on the table above, there are several words as place deixis. There is Another town, this, there, and that. The total words of place deixis are five.

Table.4 Deixis used in "The Clever Servant"

\begin{tabular}{cc}
\hline Type of Deixis & Number of Words \\
\hline Person Deixis & 19 \\
Time Deixis & 3 \\
Place Deixis & 5 \\
\hline Total & 27 \\
\hline
\end{tabular}

Based on the table above, there are several types of deixis. There is person deixis, time deixis, and place deixis. The total words of deixis are 27.

\section{Discussion}

From the data, the researchers found three types of deixis; person, time and place deixis taken from the text "The Clever Servant". First is person deixis. (Kristianto, 2016) describe that person deixis involves the speaker and addressee and operates in a basic three-part division they are; first, second and third person deixis. First person deixis (I, me, myself, mine, we, us, ourselves, our, ours. Second person deixis (you, yourself, your,and yours). As in the following sentence : He said to one of his servants, "you are the smallest, the thinnest and the weakest of 
all my servants. "The word you in the sentence above is second person deixis because it refers to his servants. Third person deixis (He, she, they, him, himself, her and herself). As in the following sentence: A rich man wanted to make a journey to another town. He was a businessman. The word he in the sentence is third-person deixis, because it refers to a rich man. The second is time deixis (The natural and prominent cycles of day and night, months, season and years). It relates to (Hasanah, Laila, 2006) that time deixis refers to time relative to time of speaking. For example : now, then, yesterday, today, tomorrow and etc. As in the following sentence :The servant's load grew smaller and lighter every day. The word every day in the sentence is time deixis, because it refers to the cycle of the day.

The third is place deixis. Place deixis is also described as spatial deixis, where the relative location of people and things is being indicated (This, these, there, here, that, and those). As in the following sentence: This was bread to eat on the journey. His master said "You are foolish. That is the biggest and heaviest load". The word that in the sentence is place deixis, because it refers to bread as the biggest and heaviest load.

Deixis is about understood between context and meaning of the conversation. (Saputri, 2015) stresses that deixis is to do with an indeterminacy that can be resolved when researchers look at the context, and particularly at three aspects of that context who the speaker is and where and when the sentence is uttered.

\section{CONCLUSION}

Following the discussion above, it can be concluded that in the recount text entitled The Clever Servants there are many types of deixis namely person, time and place deixis. Person deixis has three parts namely, first-person, second person and third-person deixis. From this data, the researchers also obtained data that there was 27 deixis. The most common type of deixis is person deixis with 19 words. Whereas place deixis has five words and then time deixis has three words.

\section{ACKNOWLEDGMENTS}

All praise may due to Allah SWT who always blesses me in every second of my life until I can finish this paper under the title "Deixis in The Clever Servant Story". Peace and salutation to Prophet Muhammad SAW who has guide us from the datkness to the lightness. I realize that my paper will never finish without some contribution from many people who give advices and critiques in order to make betterment for this paper. Therefore, I would like to express my deepest gratitude to my parents, who give me support and never stop praying for me. Above all, I would like to thank you to my lecturer, Siska Rizkiani, M.Pd, for her advices and knowledge of doing research. Finally, I as the researcher expect and need more constructive criticism and suggestion from the readers to make this paper more perfect.

\section{REFERENCES}

Apsari, Y. (2017). The Use of Picture Series in Teaching Writing Recount Text. ELTIN JOURNAL, Journal of English Language Teaching in Indonesia, 5(2), 51. https://doi.org/10.22460/eltin.v5i2.p51-56

Frans, H. G. J. (2010). The Effect of Teaching Writing Using Process-Based Approach and Product-Based Approach on the Quality Of SMA Students' Hortatory Writing. Magister Scientiae, O(28), 103-113.

Hasanah. C, Laila. M, \& Prasetyarini. A. (2006). The use of deixis in gladiator movie 
manuscript. 18.

Huang, Y. (2018). Unarticulated constituents and neo-Gricean pragmatics. Language and Linguistics, 19(1), 1-31. https://doi.org/10.1075/lali.00001.hua

Kristianto. (2016). Hospitalitas Sebagai Alat Kesadaaran Muka Dalam Interaksi Layanan Di Ranah Pariwisarta. 2.

Ondondo, E. A. (2015). Acquired Language Disorders as Barriers to Effective Communication. Theory and Practice in Language Studies, 1324. https://doi.org/10.17507/tpls.0507.02

Parmawati, A. (2018). Using Analytic Teams Technique To Improve Students'speaking Skill. Edulitics (Education, Literature, And Linguistics) Journal, 3(2), 21-25.

Saputri, K. (2015). An Analysis Of Deixis In “A Thousand Words” Movie Script. 5(1), 13-18. 